\title{
14. DETRITAL CHROMIAN SPINELS FROM SITE 960 IN THE CÔTE D'IVOIRE-GHANA TRANSFORM MARGIN' ${ }^{1}$
}

\author{
Ken-ichiro Hisada, ${ }^{2}$ Shoji Arai, ${ }^{3}$ and Takako Yamaguchi ${ }^{2}$
}

\begin{abstract}
Ocean Drilling Program Leg 159 drilled the Côte d'Ivoire-Ghana Marginal Ridge in the Atlantic Ocean. Among four drilled sites (959-962), Site 960 yielded sediments ranging in age from the Holocene to the Cretaceous. Fifteen detrital chromian spinel grains were found during petrographic examination of 30 thin sections of sandstone recovered from probably the middle Cretaceous (late Albian) Unit V at Site 960, which comprises Subunits VA and VB. High and relatively constant $\mathrm{Cr} /(\mathrm{Cr}+\mathrm{Al})$ atomic ratios of 0.7 to 0.8 and variable $\mathrm{TiO}_{2}$ content characterize these spinels. The spinels can be classified into low- and highTi groups. Low-Ti chromian spinels are more abundant in Subunit VB. The high-Ti group is very similar in chemistry to chromian spinels from intraplate and flood basalts (e.g., the Hawaiian tholeiites). It is inferred that the magma for the source rocks of these high-Ti chromian spinels was of an intraplate- or plume-type. The magma for the source rocks of the low-Ti group may have originated from the relatively Ti-depleted lithospheric mantle below the rifting continental crust. The igneous activity that produced the chromian spinels found in Leg 159 sediments may have been related to the continental breakup, having formed the Atlantic Ocean during the Barremian to Aptian stages.
\end{abstract}

\section{INTRODUCTION}

Chromian spinel is an important petrogenetic indicator in ultramafic to mafic rocks because it contains several cations as major and minor constituents. Cation ratios can change subtly according to physico-chemical conditions (Irvine, 1965, 1967). Chromian-spinel chemistry plays an important role in classifying mantle-derived peridotites in terms of origin and tectonic setting (Dick and Bullen, 1984; Arai, 1994). Chromian spinel sometimes preserves a record of equilibrium temperatures in olivine-bearing rocks (Irvine, 1967), the cooling rate of olivine-bearing magmas (Ozawa, 1985), and postcrystallization stress (Ozawa, 1989). Chromian spinel in mantlederived peridotites can also serve as an oxygen barometer of the upper mantle (Mattioli and Wood, 1986).

The chemistry of fine-grained sediments (e.g., shale) proves useful in examining the chemical characteristics of provenance rocks. Within the sandy sediments, however, heavy minerals or lithic fragments can be directly compared with possible source rocks. Chromian spinel can contain the cations $\mathrm{Mg}^{2+}, \mathrm{Fe}^{2+}, \mathrm{Fe}^{3+}, \mathrm{Cr}^{3+}, \mathrm{Al}^{3+}$, and $\mathrm{Ti}^{4+}$. Its composition is sensitive to the chemical history of the surrounding magma (Rimsaite, 1971; Arai, 1992). Even in altered or metamorphosed volcanic rocks, primary magma composition may be estimated from the composition of relict chromian spinel (Arai, 1992). Likewise, the provenance and parentage of detrital chromian spinel grains can be read from their chemistries (e.g., Middle Paleozoic to Mesozoic examples in Japan; Hisada and Arai, 1993; Hisada et al., 1995a).

The objectives for drilling the Côte d'Ivoire-Ghana Transform continental margin in the eastern equatorial Atlantic Ocean (Fig. 1A) were both tectonic and paleoceanographic (Mascle et al., 1996). The main tectonic objective was to better understand the evolution of transform continental margins. Four sites were drilled during Leg 159 (Sites 959-962) into the continental crust adjacent to the continent/ocean transition along the transform margin (Fig. 1B). Three

'Mascle, J., Lohmann, G.P., and Moullade, M. (Eds.), 1998, Proc. ODP, Sci. Results, 159: College Station, TX (Ocean Drilling Program).

${ }^{2}$ Institute of Geoscience, University of Tsukuba, Tsukuba, Ibaraki 305, Japan. hisadak@arsia.geo.tsukuba.ac.jp

${ }^{3}$ Department of Earth Sciences, Kanazawa University, Kanazawa 920-11, Japan. principal paleoenvironmental settings were identified: (1) the Intracontinental to Syntransform Basin Stage; (2) the Marginal Ridge Emergence Stage; and (3) the Passive Margin Stage (Mascle, Lohmann, Clift, et al., 1996).

We have identified several detrital chromian spinel grains from Unit V at Site 960, which corresponds to the Intracontinental to Syntransform Basin Stage (Hisada et al., 1995b). In this paper, we describe the occurrence and chemistry of these detrital chromian spinels and discuss their tectonic significance.

\section{PALEOENVIRONMENT OF UNIT V AT SITE 960}

Unit $\mathrm{V}$ is the lowermost unit at Site 960. It is divided into two lithologic subunits (VA and VB; Fig. 2). Subunit VA comprises fineto medium-grained, cross-bedded to parallel-laminated, micritic sandstone, and massive black claystone associated with siderite, marcasite, and pyrite (Mascle, Lohmann, Clift, et al., 1996). The subunit grades downward into lithologic Subunit VB, which consists of finely laminated black to gray siltstone and silty sandstone with some intercalated siltstone beds.

The principal difference between Subunits VA and VB is the presence of millimeter-scale parallel laminations in Subunit VB (Mascle, Lohmann, Clift, et al., 1996). Parallel laminations are much more prominent in the silty claystone than in other lithologies, in particular from Cores 159-960A-54R through 58R, where alternating lighter and darker laminae are $0.5-2 \mathrm{~mm}$ thick and continuous across the core. The darker laminae are richer in plant fragments and carbonaceous material, whereas the lighter laminae are more quartz rich. This laminated lithology is referred to as rhythmite or varves (Mascle, Lohmann, Clift, et al., 1996), and is ascribed to depositon in a freshwater lake (Reineck and Singh, 1980; cf. Deep Sea Drilling Project Site 380 in the Black Sea, Shipboard Scientific Party, 1978).

The lower part of Subunit VB consists mainly of alternating silty sandstone, sandy siltstone, and subordinate clayey siltstone and silty claystone. Here, normally graded beds with scoured basal contacts suggest that density currents periodically deposited these sediments within the lake. In Subunit VA, claystones are slightly to heavily bioturbated and contain a few marine fossils. If interpretation of Subunit $\mathrm{VB}$ as a deep lacustrine environment is correct, then Subunit VA 
Figure 1. Geodynamic framework of (A) the Côte d'Ivoire-Ghana Transform Margin and (B) a series of coring sites (Sites 959-962). Boxed region in (A) is shown in more detail in (B).
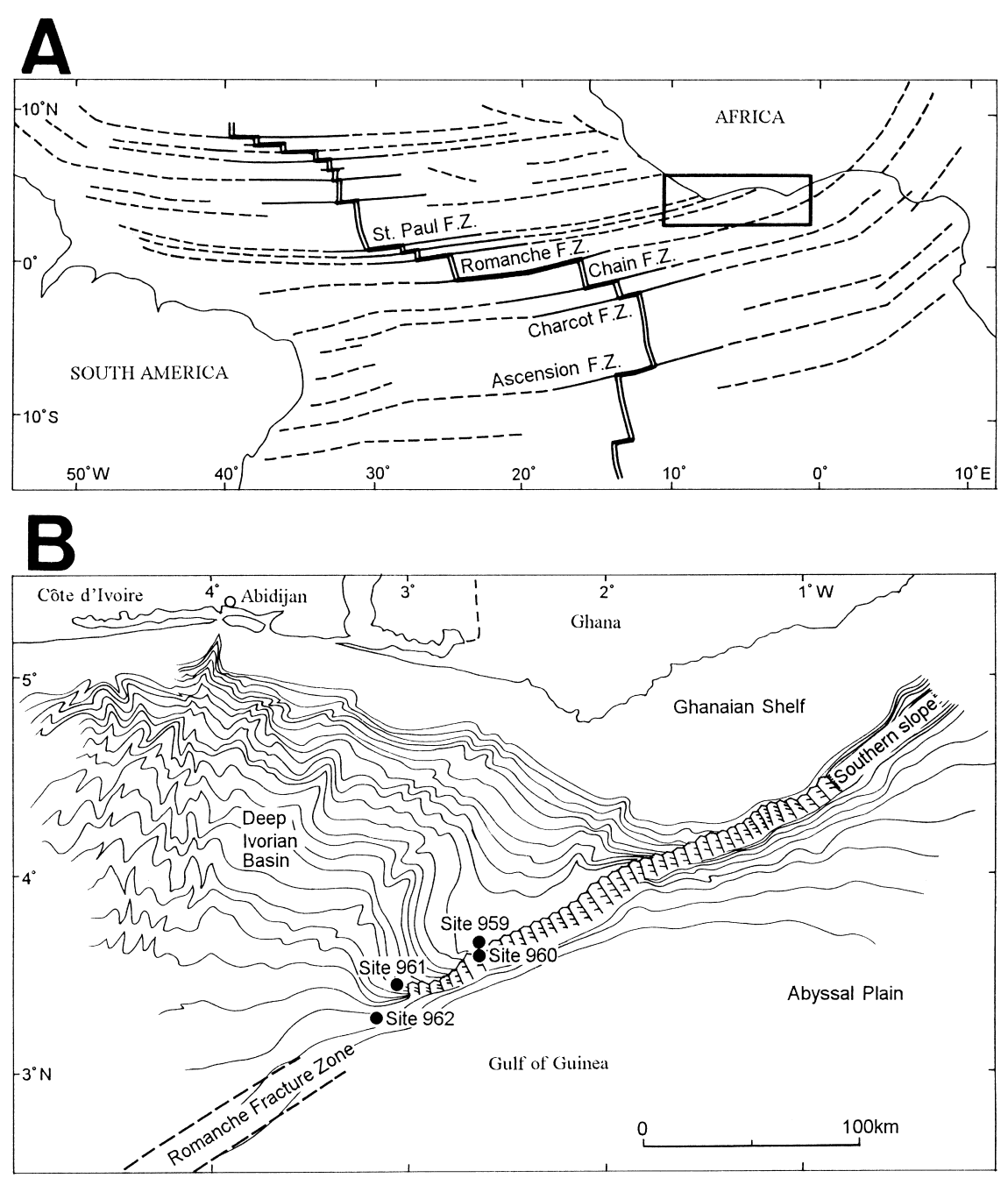

could reflect the onset of brackish conditions as a result of inundation by marine water (Mascle, Lohmann, Clift, et al., 1996).

Unit V contains no calcareous or siliceous microfossils. The overlying Unit IV is dated as Santonian/Coniacian to Turonian based on calcareous nannofossils. Thus, Unit V is likely pre-Turonian. Moreover, judging from correlations to other Leg 159 sites, Unit V is probably Cenomanian to Albian (Mascle, Lohmann, Clift, et al., 1996).

\section{OCCURRENCE OF CHROMIAN SPINELS}

Fifteen chromian spinel grains were identified in 30 thin sections of sandstone specimens spanning Unit V at Site 960. The samples were taken at intervals of a few meters to a few tens of meters throughout Unit V. The sandstone specimens do not exceed medium grain size, are light to medium gray, and are laminated. Neither volcanic rock fragment nor pyroxene grains were found when examined under the microscope, whereas tourmaline is occasionally observed.

Samples containing chromian spinel grain(s) are listed in Table 1 and plotted stratigraphically in Figure 2. Photomicrographs of all detrital chromian spinels are shown in Plate 1.

The amount of detrital chromian spinel is very low, one grain typically being found per thin section. One sample (159-960A-59R-1, $106-107 \mathrm{~cm}$ ) has an exceptionally high content of spinel; four grains are present in this thin section. Subunits VA and VB yielded five and 10 grains, respectively.
The chromian spinels are usually opaque or, rarely, translucent, with colors of reddish and yellowish brown (Table 1). The long diameter ranges from 20 to $70 \mu \mathrm{m}$ (Table 1). Some spinel grains are euhedral, whereas others have an angular shape, suggesting fragmentation (Pl. 1).

\section{CHEMISTRY OF CHROMIAN SPINELS}

Chromian spinels were analyzed with a JEOL 8621 microprobe at the Chemical Analysis Center, University of Tsukuba. All analyses are listed in Table 2. Cationic ratios were calculated assuming spinel stoichiometry, and all $\mathrm{Ti}$ was assigned to ulvospinel molecule $\mathrm{Fe}_{2} \mathrm{TiO}_{4}$.

Chromian spinels demonstrate a wide compositional range (Figs. $3-6)$. The $\mathrm{Cr} \#(\mathrm{Cr} /(\mathrm{Cr}+\mathrm{Al})$ atomic ratio) varies from 0.3 to 0.8 , but is mostly around 0.7 to 0.8 (Figs. 3, 4). For convenience, we divide the spinels into a high-Ti group and a low-Ti group (Fig. 3). The high-Ti spinels ( $>1 \mathrm{wt} \% \mathrm{TiO}_{2}$ ) have relatively constant $\mathrm{Cr} \# \mathrm{~s}, 0.7$ to 0.8 (Figs. $3,4)$, and high and variable $\mathrm{Fe}^{3+} /\left(\mathrm{Fe}^{3+}+\mathrm{Al}+\mathrm{Cr}\right.$ ) ratios (Figs. 5, 6). These compositional features of the high-Ti spinels are very similar to those of spinels in Hawaiian and other intraplate tholeiites (Basaltic Volcanism Study Project, 1981). The $\mathrm{Mg} \#\left(\mathrm{Mg} /\left(\mathrm{Mg}+\mathrm{Fe}^{2+}\right)\right.$ atomic ratio), especially for low-Ti spinels, does not correlate with the $\mathrm{Cr} \#$ (Fig. 4). The $\mathrm{TiO}_{2}$ content is positively correlated with the $\mathrm{Fe}^{3+}$ $\left(\mathrm{Fe}^{3+}+\mathrm{Al}+\mathrm{Cr}\right.$ ) atomic ratio (Fig. 6). 


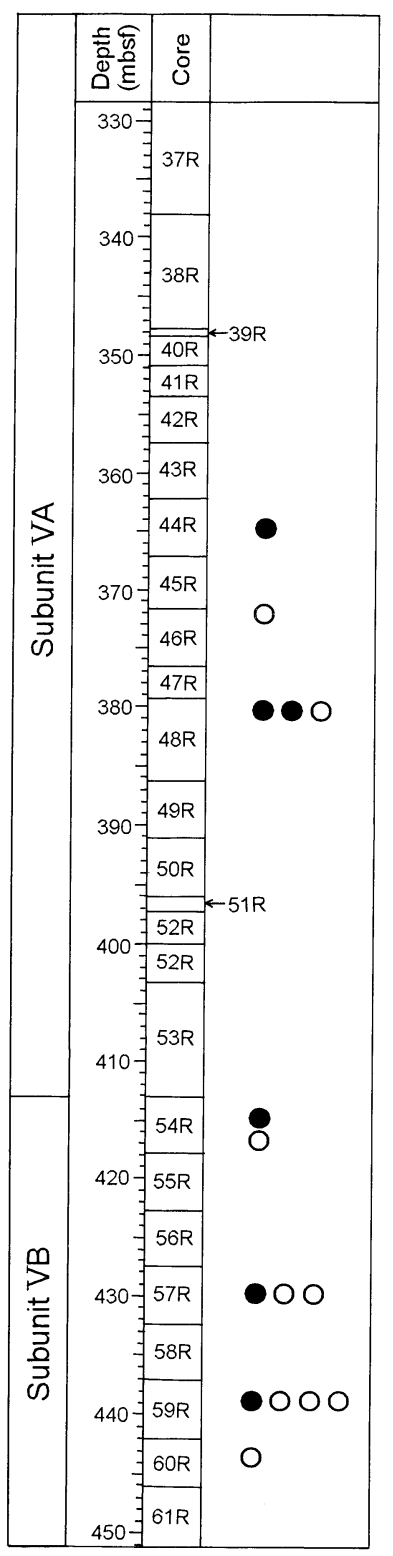

Figure 2. Columnar section showing occurrences of chromian spinel in Unit $\mathrm{V}$ at Site 960. Open circles = low-Ti chromian spinels; solid circles $=$ high-Ti chromian spinels.

Table 1. Color and size of chromian spinels under the microscope.

\begin{tabular}{rlcl}
\hline Grain & $\begin{array}{c}\text { Core, section, } \\
\text { interval }(\mathrm{cm})\end{array}$ & $\begin{array}{c}\text { Long diameter } \\
(\mu \mathrm{m})\end{array}$ & \multicolumn{1}{c}{ Color } \\
\hline & 159-960A- & & \\
1 & 44R-2, 109-112 & 35 & Black \\
2 & 46R-CC, 7-10 & 60 & Black \\
3 & 48R-CC, 16-019 & 35 & Black \\
4 & 48R-CC, 16-019 & 35 & Black \\
5 & 48R-CC, 16-19 & 30 & Black \\
6 & 54R-1, 111-113 & 40 & Black \\
7 & 54R-2, 53-055 & 70 & Black \\
8 & 57R-2, 6-9 & 30 & Black \\
9 & 57R-2, 6-9 & 50 & Black \\
10 & 57R-2, 6-9 & 20 & Yellowish brown \\
11 & 59R-1, 106-107 & 60 & Reddish brown \\
12 & 59R-1, 106-107 & 40 & Black \\
13 & 59R-1, 106-107 & 35 & Black \\
14 & 59R-1, 106-107 & 30 & Black \\
15 & 60R-1, 74-076 & 40 & Reddish brown \\
\hline
\end{tabular}

\section{TWO GROUPS OF CHROMIAN SPINELS}

The high-Ti group (Pl. 1) is almost opaque and 30-40 $\mu \mathrm{m}$ in long diameter. The low-Ti group is mainly opaque but is rarely translucent, reddish to yellowish brown, and consists of grains $20-70 \mu \mathrm{m}$ in long diameter. Angular and square shapes are typical of the low-Ti group.

There is a slight difference between the two groups in terms of their distribution in Unit V (Fig. 2). Grains of the low-Ti group occur predominantly in Subunit VB, gradually decreasing in number uphole. The high-Ti group occurs equally in the two subunits. Both high- and low-Ti grains are present in Sample 159-960A-59R-1, 106-107 cm (Pl. 1, Fig. 2).

\section{DISCUSSION}

\section{Provenance of the Detrital Spinels}

The chemical characteristics of the detrital chromian spinels indicate their derivation from intraplate tholeiitic rocks. The $\mathrm{Cr} \#-\mathrm{TiO}_{2}$ relationship, that is, both a relatively high $\mathrm{Cr} \#(0.7$ to 0.8$)$ and $\mathrm{TiO}_{2}$ content (up to $8 \mathrm{wt} \%$ ) (Fig. 3), is very similar to those of spinels from intraplate tholeiites, including continental flood basalts (Arai, 1992). The Cr-Al-Fe ${ }^{3+}$ relations (Fig. 5) are also similar to those for spinels in intraplate tholeiites (Ishida et al., 1990). The discrimination diagram of Arai (1992) for spinels with high $\mathrm{Fe}^{3+} /\left(\mathrm{Fe}^{3+}+\mathrm{Al}+\mathrm{Cr}\right)$ ratios suggests derivation from intraplate magmas (Fig. 6), although these detrital spinels have Cr\#s outside the range (0.3-0.6) for which the discrimination diagram was derived. The wide variety of $\mathrm{TiO}_{2}$ content of spinel indicates a wide chemical variety of magma, especially for $\mathrm{TiO}_{2}$ content (Arai, 1992).

The reconstruction map for Africa-South America before the opening of the Equatorial Atlantic (Wilson and Guiraud, 1992) permits tholeiitic basalts in modern northern Brazil to have been a source for the detrital spinels. In northern Brazil, there are widespread occurrences of magmatic rocks, mainly with tholeiitic characteristics, which can be correlated with the various phases of the opening of the Central and Equatorial Atlantic. Zalan et al. (1985) indicate that the basalts are interbedded with sandstone and shale, which are assigned to approximately the Aptian in the Piaui Basin of northern Brazil. The Piaui Basin has been regarded as the counterpart of the Côte d'IvoireGhana Transform Margin on the opposite end of the Romanche Fracture Zone. Reyre (1984) documents Cretaceous volcano-sedimentary alternations in an industry borehole on the Ghanaian shelf, $75 \mathrm{~km}$ southwest of Takoradi in Ghana. The remnants of Mesozoic flood basalts and related hypabyssal rocks are widely distributed in the Maranhão region of northern Brazil. The continental flood basalt related to the continental breakup has been known to have a wide range of $\mathrm{TiO}_{2}$ content even within a region, depending on the diversity of involved source mantle, that is, plume or lithospheric mantle (Fodor et al., 1990; Garland et al., 1996). Fodor et al. (1990) divided tholeiitic basalts into low-Ti (160-190 Ma) and high-Ti (115-122 Ma) types according to chemical analyses and K-Ar ages, and concluded that the Maranhão low-Ti magmas were probably related to the opening of the central North Atlantic and high-Ti magmas to the opening of the equatorial Atlantic. The Jurassic 160- to 190-Ma flood basalts may have been related to the activity of a mantle hot spot, the St. Helena hot spot (Morgan, 1983). The wide $\mathrm{TiO}_{2}$ range of detrital spinel possibly corresponds to the wide $\mathrm{TiO}_{2}$ range of magma chemistry in source flood basalts. The 115 to 122-Ma tholeiitic basalts (Barremian to Aptian) are postulated to be source rocks for the detrital chromian spinels in Unit V at Site 960. The slight stratigraphic change of a high-Ti spinel/low-Ti spinel ratio (Fig. 2) possibly indicates a temporal change of source basalt chemistry, that is, a temporal change of erupted basalt chemistry; low-Ti basalt erupted at an earlier stage of the continental breakup than high-Ti basalt. 


\begin{tabular}{|c|c|c|c|c|c|c|c|c|c|c|c|c|c|c|c|}
\hline Grain number: & 1 & 2 & 3 & 4 & 5 & 6 & 7 & 8 & 9 & 10 & 11 & 12 & 13 & 14 & 15 \\
\hline $\mathrm{SiO}_{2}$ & 1.81 & 0.15 & 0.12 & 0.05 & 0.34 & 0.69 & 0.07 & 0.23 & 0.26 & 0.75 & 0.06 & 0.23 & 0.38 & 0.07 & 0.01 \\
\hline $\mathrm{Al}_{2} \mathrm{O}_{3}$ & $\begin{array}{l}1.01 \\
5.05\end{array}$ & 14.08 & 7.32 & 5.12 & 7.74 & 11.47 & 9.97 & 7.96 & 21.19 & 34.68 & 40.14 & 14.14 & 10.15 & 11.24 & 12.25 \\
\hline $\begin{array}{l}\mathrm{A}_{2} \mathrm{O}_{3} \\
\mathrm{TiO}_{2}\end{array}$ & $\begin{array}{l}3.05 \\
3.05\end{array}$ & $\begin{array}{r}14.08 \\
0.21\end{array}$ & $\begin{array}{l}.32 \\
0.07\end{array}$ & $\begin{array}{l}5.12 \\
7.69\end{array}$ & $\begin{array}{l}1.14 \\
1.60\end{array}$ & $\begin{array}{r}1.47 \\
0.97\end{array}$ & $\begin{array}{l}9.91 \\
0.31\end{array}$ & $\begin{array}{r}.90 \\
4.70\end{array}$ & $\begin{array}{r}2.19 \\
0.29\end{array}$ & $\begin{array}{r}34.08 \\
0.12\end{array}$ & $\begin{array}{r}40.14 \\
0.06\end{array}$ & $\begin{array}{r}14.14 \\
1.47\end{array}$ & $\begin{array}{r}1.13 \\
0.37\end{array}$ & $\begin{array}{r}11.24 \\
0.07\end{array}$ & $\begin{array}{r}1.25 \\
0.04\end{array}$ \\
\hline $\mathrm{Cr}_{2} \mathrm{O}_{3}$ & 42.68 & 51.53 & 55.32 & 24.41 & 38.01 & 45.95 & $\begin{array}{r}4.31 \\
47.82\end{array}$ & 29.22 & $\begin{array}{r}42.80 \\
\end{array}$ & $\begin{array}{r}0.12 \\
24.38\end{array}$ & 28.54 & $\begin{array}{r}1.47 \\
42.37\end{array}$ & 57.17 & 60.76 & $\begin{array}{r}55.54 \\
54\end{array}$ \\
\hline 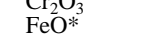 & $\begin{array}{l}39.08 \\
39.56\end{array}$ & 23.81 & 28.73 & $\begin{array}{l}24.41 \\
51.35\end{array}$ & $\begin{array}{l}3.01 \\
41.31\end{array}$ & 28.45 & $\begin{array}{l}4.82 \\
26.41\end{array}$ & 48.65 & $\begin{array}{l}42.80 \\
22.20\end{array}$ & $\begin{array}{l}27.08 \\
27.07\end{array}$ & $\begin{array}{l}2.34 \\
17.44\end{array}$ & 31.47 & 12.17 & $\begin{array}{l}0.10 \\
15.25\end{array}$ & $\begin{array}{l}5.54 \\
16.33\end{array}$ \\
\hline $\mathrm{NiO}$ & 0.09 & 0.04 & 0.01 & 0.16 & 0.08 & 0.12 & 0.07 & 0.14 & 0.10 & 0.25 & 0.13 & 0.06 & 0.17 & 0.02 & 0.05 \\
\hline $\mathrm{MnO}$ & 0.92 & 0.58 & 0.47 & $\begin{array}{l}0.10 \\
0.39\end{array}$ & 0.38 & 0.34 & 3.92 & 0.43 & $\begin{array}{l}0.10 \\
0.29\end{array}$ & 0.16 & 0.21 & 0.33 & 0.65 & 0.53 & 2.19 \\
\hline $\mathrm{MgO}$ & 2.00 & 5.45 & 3.96 & 4.39 & 4.86 & 7.98 & 4.07 & 4.47 & 10.90 & 8.85 & 11.93 & 5.92 & 16.11 & 11.82 & 8.59 \\
\hline $\mathrm{CaO}$ & 0.01 & 0.03 & 0.23 & 0.52 & 0.45 & 0.02 & 0.01 & 0.00 & 0.01 & 0.01 & 0.14 & 0.11 & 0.28 & 0.28 & 0.14 \\
\hline $\mathrm{Na}_{2} \mathrm{O}$ & 0.16 & 0.02 & 0.08 & 0.01 & & 0.01 & 0.07 & 0.08 & 0.04 & & 0.02 & - & - & 0.01 & - \\
\hline $\mathrm{K}_{2} \mathrm{O}$ & 0.03 & 0.02 & & & $0 . \overline{01}$ & 0.02 & 0.01 & 0.02 & 0.01 & $0 . \overline{02}$ & & - & - & 0.02 & - \\
\hline Total & 95.36 & 95.92 & 96.31 & 94.09 & 94.78 & 96.02 & 92.73 & 95.90 & 98.09 & 96.29 & 98.67 & 96.10 & 97.45 & 100.07 & 95.14 \\
\hline $\mathrm{Al}$ & 0.2269 & 0.5758 & 0.3151 & 0.2411 & 0.3489 & 0.4756 & 0.4410 & 0.3602 & 0.8034 & 1.2763 & 1.3729 & 0.5872 & 0.3915 & 0.4296 & 0.4973 \\
\hline $\mathrm{Ti}$ & 0.0874 & 0.0055 & 0.0020 & 0.2309 & 0.04 & 0.0255 & 0.0087 & 0.1356 & & 0.0029 & 0.0013 & 0.0389 & 0.0090 & 0.0017 & 0.0011 \\
\hline $\mathrm{Cr}$ & 1.2875 & 1.4140 & 1.5971 & 0.7706 & 1.1501 & 1.2780 & 1.4194 & 0.8871 & 1.0885 & 0.6019 & 0.6549 & 1.1807 & 1.4792 & 1.5580 & 1.5128 \\
\hline $\mathrm{Fe}$ & 1.2623 & 0.6911 & 0.8773 & 1.7143 & 1.3224 & 0.8369 & 0.8290 & 1.5625 & 0.5972 & 0.7069 & 0.4233 & 0.9276 & 0.3330 & 0.4137 & 0.4705 \\
\hline Mn & 0.0296 & 0.0171 & 0.0145 & 0.0132 & 0.0122 & 0.0101 & 0.1246 & 0.0140 & 0.0079 & 0.0043 & 0.0052 & 0.0100 & 0.0179 & 0.0146 & 0.0640 \\
\hline $\mathrm{Mg}$ & 0.1136 & 0.2821 & 0.2152 & 0.2612 & 0.2775 & 0.4182 & 0.2279 & 0.2559 & 0.5225 & 0.4119 & 0.5159 & 0.3111 & 0.7860 & 0.5712 & 0.4412 \\
\hline $\mathrm{Cr} \#$ & 0.85 & 0.71 & 0.84 & 0.76 & 0.77 & 0.73 & 0.76 & 0.71 & 0.58 & 0.32 & 0.32 & 0.67 & 0.79 & 0.78 & 0.75 \\
\hline Mg\# & 0.12 & 0.29 & 0.21 & 0.31 & 0.28 & 0.42 & 0.23 & 0.2 & 0.52 & 0.41 & 0.52 & 0.32 & 0.79 & 0.57 & 0.44 \\
\hline $\mathrm{Fe} 3 \#$ & 0.17 & 0.00 & 0.05 & 0.40 & 0.26 & 0.11 & 0.08 & 0.33 & 0.06 & 0.06 & 0.00 & 0.10 & 0.06 & 0.00 & 0.00 \\
\hline Al3\# & 0.12 & 0.29 & 0.16 & 0.14 & 0.17 & 0.24 & 0.22 & 0.19 & 0.40 & 0.64 & 0.69 & 0.30 & 0.20 & 0.22 & 0.25 \\
\hline $\mathrm{Cr} 3 \#$ & 0.70 & 0.71 & 0.79 & 0.46 & 0.57 & 0.65 & 0.70 & 0.47 & 0.54 & 0.30 & 0.33 & 0.60 & 0.74 & 0.78 & 0.76 \\
\hline
\end{tabular}

Notes: $\mathrm{Grain}$ numbers correspond to those listed in $\mathrm{Table} 1 . \mathrm{FeO} *=$ total ion as $\mathrm{FeO}, \mathrm{Cr} \#=\mathrm{Cr} /(\mathrm{Cr}+\mathrm{Al})$ atomic ratio, $\mathrm{Mg} \#=\mathrm{Mg} /\left(\mathrm{Mg}+\mathrm{Fe}^{2+}\right)$ atomic ratio, $\mathrm{Fe} 3 \#=\mathrm{Fe}{ }^{3+} /\left(\mathrm{Al}+\mathrm{Cr}+\mathrm{Fe} e^{3+}\right), \mathrm{Al} 3 \#=\mathrm{Al} /\left(\mathrm{Al}+\mathrm{Cr}+\mathrm{Fe}{ }^{3+}\right), \mathrm{Cr} 3 \#=\mathrm{Cr} /\left(\mathrm{Al}+\mathrm{Cr}+\mathrm{Fe}^{3+}\right)$. Ratios of $\mathrm{Fe}^{2+}$ and $\mathrm{Fe}^{3+}$ were calculated assuming spinel stoichiometry. $-=$ not determined. 


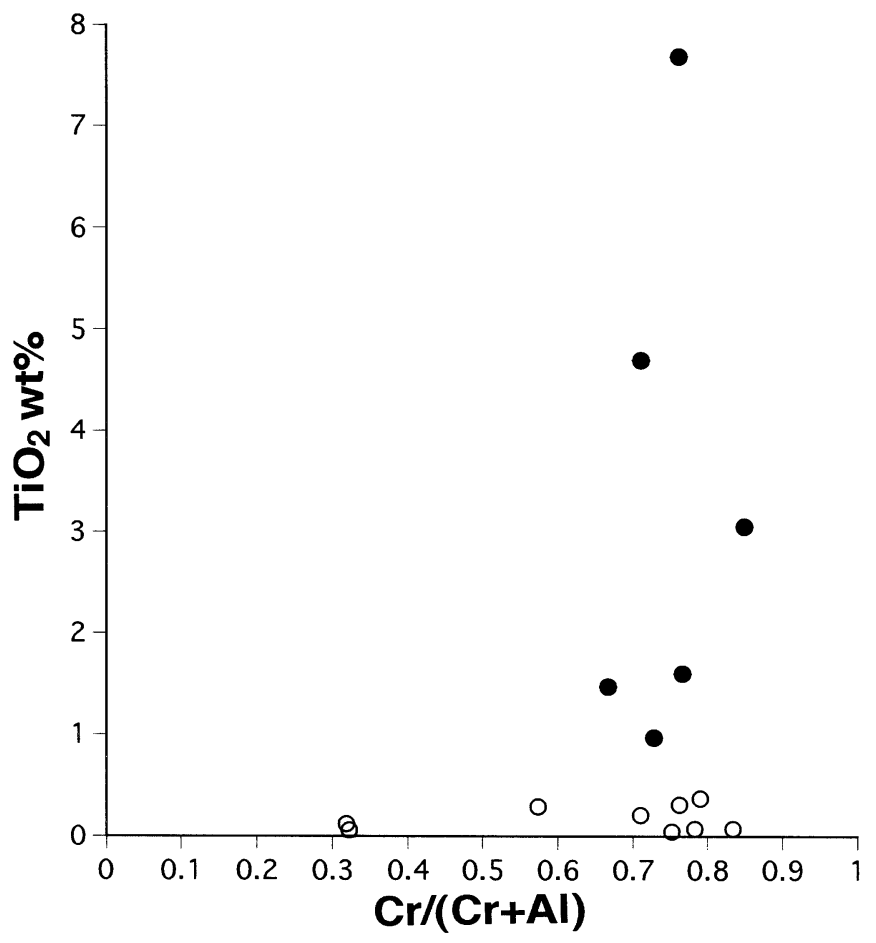

Figure 3. Relationship between $\mathrm{Cr} /(\mathrm{Cr}+\mathrm{Al})$ and $\mathrm{TiO}_{2}$ content in chromian spinels. Symbols as in Figure 2.

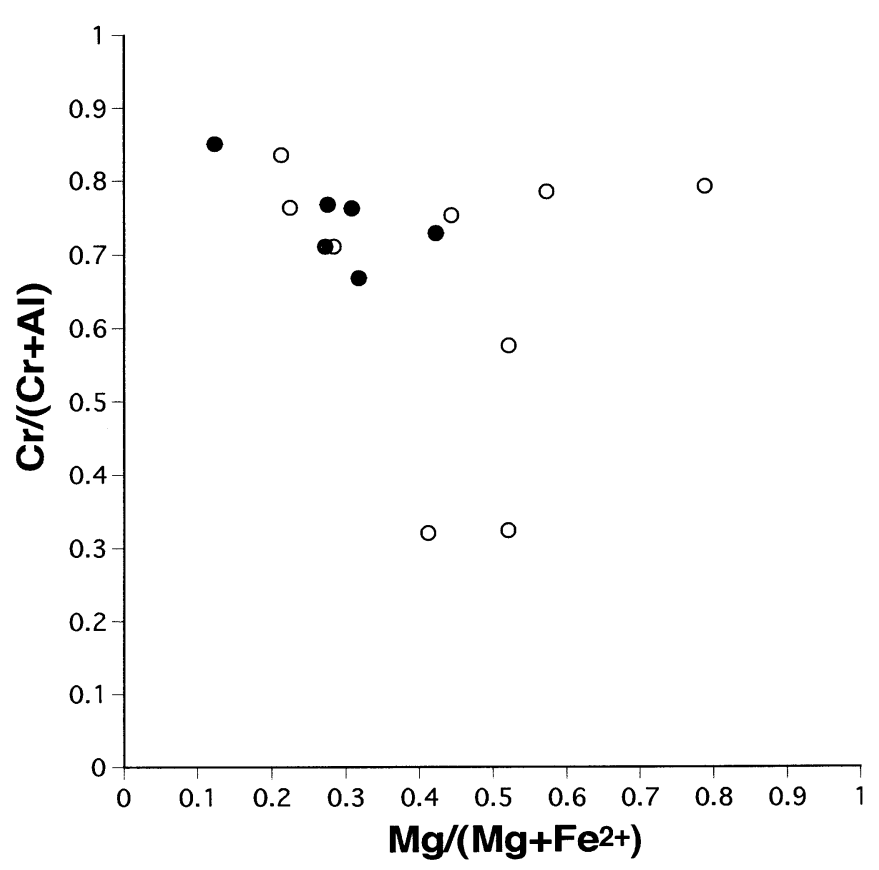

Figure 4. Relationship between $\mathrm{Mg} /\left(\mathrm{Mg}+\mathrm{Fe}^{2+}\right)$ and $\mathrm{Cr} /(\mathrm{Cr}+\mathrm{Al})$ in chromian spinels. Symbols as in Figure 2.

\section{Relationship Between Tectonics, Sedimentation, and Magmatism}

Morgan (1983) postulated that hot-spot tracks appear to become the locus of later rifting because the heat of the hot spot weakens the lithosphere and thereby facilitates the splitting of the continents along these weakened lines tens of millions of years later. He also gave ex-

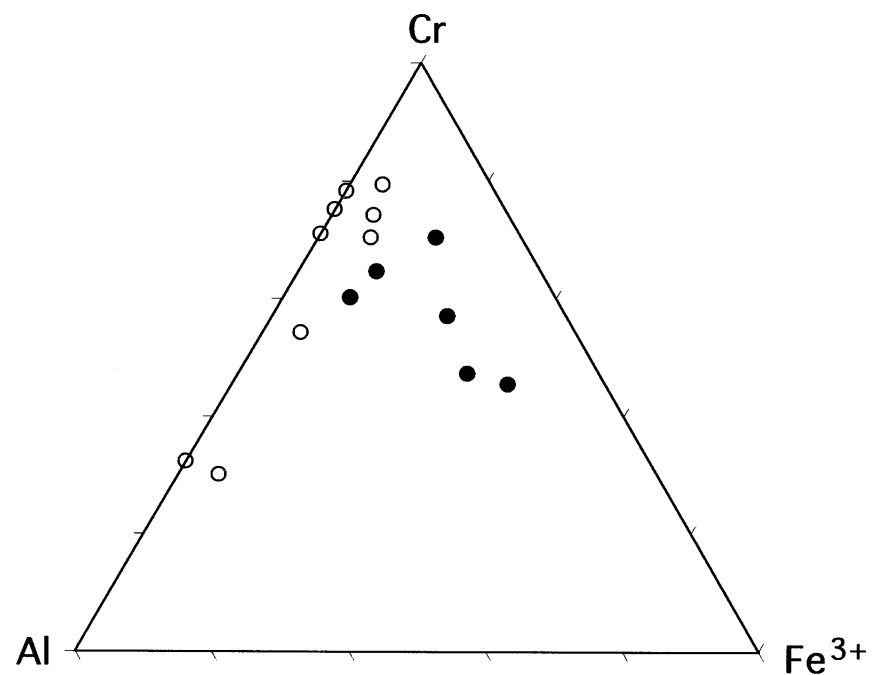

Figure 5. $\mathrm{Cr} / \mathrm{Al} / \mathrm{Fe}^{3+}$ ratios of detrital chromian spinels. Symbols as in Figure 2.

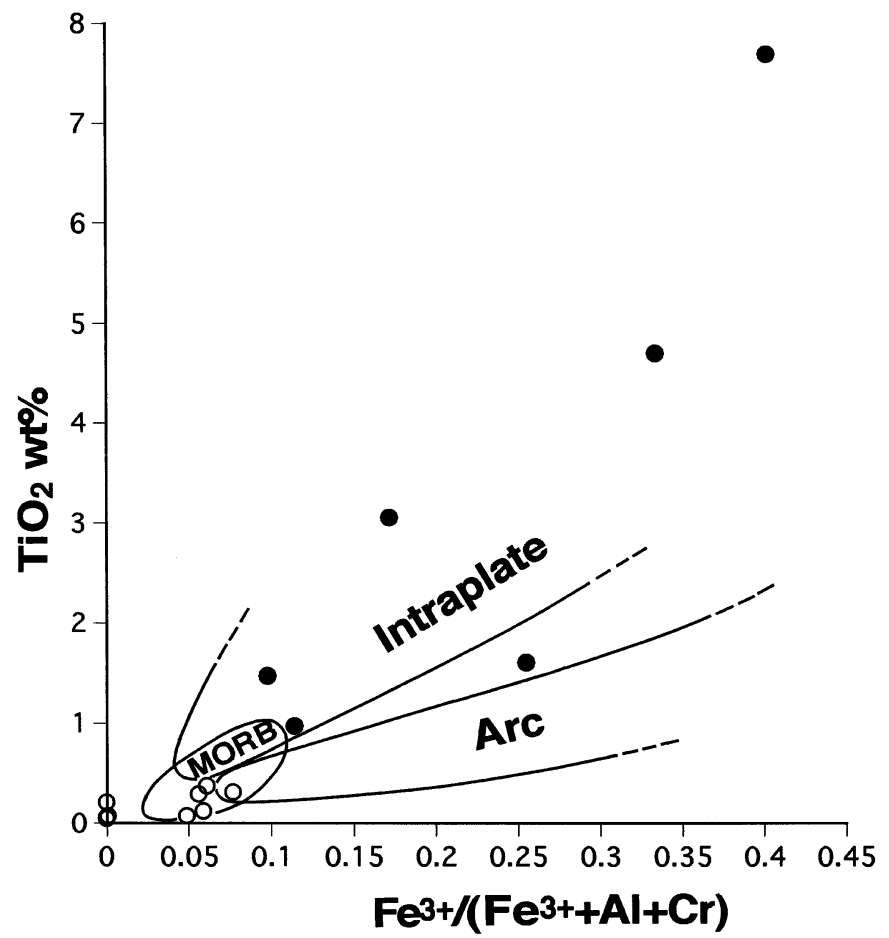

Figure 6. Relationship between $\mathrm{Fe}^{3+} /\left(\mathrm{Fe}^{3+}+\mathrm{Al}+\mathrm{Cr}\right)$ and $\mathrm{TiO}_{2}$ content in chromian spinels. Symbols as in Figure 2. Discrimination lines are from Arai (1992)

amples of the west coast of Greenland/east coast of Labrador (Madeira hot spot), the south coast of West Africa/north coast of Brazil (St. Helena hot spot) and others. Recently, Wilson and Guiraud (1992) reviewed Mesozoic-Cenozoic magmatic activity in West and Central Africa and northern Brazil with particular emphasis on the relationship between Mesozoic magmatism, major phases of continental rifting, and the opening of the Equatorial Atlantic. They suggested that during the initial stages of rifting, the activity of a mantle plume, the St. Helena hot spot, may have been important in weakening the lithosphere across the region. 
The rifting is indicated to be polyphase (Guiraud and Maurin, 1992). The first rifting was initiated during the earliest Neocomian, and the second rifting phase commenced during the middle-late Aptian. The coastal basins of the Ivory Coast during the Albian are inferred to have been subjected to the transition from a rift phase to a passive margin phase (Guiraud and Maurin, 1992). The very thick continental clastics were deformed because of dextral transtensional and transpressional motions along major shear faults, as indicated by the presence of pull-apart basins and folded highs (Mascle, Lohmann, Clift, et al., 1988; Basile et al., 1992). Thus, geomorphologically rugged features such as basin and range may be produced along major shear faults (Mascle, Lohmann, Clift, et al., 1996). Unit V was probably deposited in such a transform basin, which was temporarily a lacustrine environment during the Albian. The clastics that contain chromian spinels probably entered the transform basin through valleys developed along major shear faults. This sedimentation postdates Barremian to Aptian rift-phase magmatism.

\section{CONCLUSIONS}

Fifteen chromian spinels were obtained from lithologic Unit $\mathrm{V}$ at Site 960. Unit V is inferred to have been deposited in freshwater to brackish water environments, which characterized basins formed in a transform setting during the continental breakup of West Africa and South America during the Albian. These chromian spinels are divided into high-Ti and low-Ti groups based on the grain color, shape, size, and chemistry. The high-Ti and low-Ti chromian spinels may have been derived, respectively, from magma feeding intraplate basalts and from magma derived from the Ti-depleted mantle below the continental crust. Tholeiitic basalt magmatism is known from the Ghanaian shelf and northern Brazil. The radiometric ages of these tholeiite basalts are 115-122 Ma, that is, Barremian to Aptian. Therefore, the magmatism inferred from the chemistry of the detrital chromian spinels appears to be correlatable to Barremian to Aptian tholeiitic magmatism above the St. Helena hot spot.

\section{ACKNOWLEDGMENTS}

Ken-ichiro Hisada is indebted to the Ocean Drilling Program, the Leg 159 Shipboard Scientific Party, and the Sedco and Schlumberger shipboard crews, who provided the geologic background and samples for this research, and especially to the other Leg 159 sedimentologists, Maryanne Holmes, Kyger C. Lohmann, Francisca E. Oboh, Thomas Pletch, and Kari O. Strand. We also wish to thank Christophe Basile for finding important references. We are grateful to Kazutoshi Suzaki and Makoto Miyamoto for making thin sections, and Norimasa Nishida for analytical advice.

\section{REFERENCES}

Arai, S., 1992. Chemistry of chromian spinels in volcanic rocks as a potential guide to magma chemistry. Mineral. Mag., 56:173-184.

- 1994. Characterization of spinel peridotites by olivine-spinel compositional relationships: review and interpretation. Chem. Geol., 113:191-204.

Basaltic Volcanism Study Project (BSVP), 1981. Basaltic Volcanism on the Terrestrial Planets: New York (Pergamon Press).

Basile, C., Brun, J.P., and Mascle, J., 1992. Structure et formation de la marge transformante de Côte d'Ivoire-Ghana: apports de la sismique réflexion et de la modélisation analogique. Bull. Soc. Geol. Fr., 163:207216.

Dick, H.J.B., and Bullen, T., 1984. Chromian spinel as a petrogenetic indicator in abyssal and alpine-type peridotites and spatially associated lavas. Contrib. Mineral. Petrol., 86:54-76.

Fodor, R.V., Sial, A.N., Mukasa, S.B., and McKee, E.H., 1990. Petrology, isotope characteristics and K-Ar ages of the Maranhao, northern Brazil, Mesozoic basalt province. Contrib. Mineral. Petrol., 104:555-567.

Garland, F., Turner, S., and Hawkesworth, C., 1996. Shifts in the source of the Paraná basalts through time. Lithos, 37:223-243.

Guiraud, R., and Maurin, J.C., 1992. Early Cretaceous rifts of western and Central Africa: an overview. Tectonophysics, 213:153-168.

Hisada, K., and Arai, S., 1993. Detrital chrome spinels in the Cretaceous Sanchu sandstone, central Japan: indicator of serpentinite protrusion into a fore-arc region. Palaeogeogr., Palaeoclimatol., Palaeoecol., 105:95109.

Hisada, K., Arai, S., and Ishii T., 1995a. Occurrence of detrital chromianspinels and its implication: tectonic setting of Matsugadaira-Motai belt, NE Japan. Ann. Rep., Inst. Geosci., Univ. Tsukuba., 21:15-19.

Hisada, K., Ishii, T., Arai, S., and Leg 159 Shipboard Scientific Party, 1995b. Detrital chrome spinels in Hole 960A, CIGMR. Eos, 76:596-597.

Irvine, T.N., 1965. Chromium spinel as a petrogenetic indicator, Part 1: theory. Can. J. Earth Sci., 2:648-672.

, 1967. Chromium spinel as a petrogenetic indicator, Part 2: petrological applications. Can. J. Earth Sci., 4:71-103.

Ishida, T., Arai, S., and Takahashi, N., 1990. Metamorphosed picrite basalts in the northern part of the Setogawa belt, central Japan. J. Geol. Soc. Jpn., 96:181-191.

Mascle, J., Blarez, E., and Marinho, M., 1988. The shallow structures of the Guinea and Ivory Coast-Ghana transform margins: their bearing on the Equatorial Atlantic Mesozoic evolution. Tectonophysics, 188:193-209.

Mascle, J., Lohmann, G.P., Clift, P.D., et al., 1996. Proc. ODP, Init. Repts., 159: College Station, TX (Ocean Drilling Program).

Mattioli, G.S., and Wood, B.J., 1986. Upper mantle oxygen fugacity recorded by spinel Iherzolites. Nature, 322:626-7.

Morgan, W.J., 1983. Hotspot tracks and the early rifting of the Atlantic. Tectonophysics, 94:123-139.

Ozawa, K., 1985. Olivine-spinel geospeedometry: analysis of diffusion-controlled Mg-Fe ${ }^{2+}$ exchange. Geochim. Cosmochim. Acta, 48:2597-2611.

, 1989. Stress-induced Al-Cr zoning of spinel in deformed peridotites. Nature, 338:141-144.

Reineck, H.E., and Singh, I.B., 1980. Depositional Sedimentary Environments (2nd ed.): Berlin (Springer-Verlag).

Reyre, D., 1984. Remarques sur l'origine et l'évolution des bassins sédimentaires africains de la côte atlantique. Bull. Soc. Geol. Fr., Ser. 7, 26:10411059.

Rimsaite, J., 1971. Distribution of major and minor constituents between mica and host ultrabasic rocks, and between zoned mica and zoned spinel. Contrib. Mineral. Petrol., 33:259-272.

Shipboard Scientific Party, 1978. Site 380. In Ross, D.A., Neprochnov, Y.P., et al., Init. Repts. DSDP, 42 (Pt. 2): Washington (U.S. Govt. Printing Office), 119-291.

Wilson, M., and Guiraud, R., 1992. Magmatism and rifting in Western and Central Africa, from Late Jurassic to Recent times. Tectonophysics, 213:203-225.

Zalan, P.V., Nelson, E.P., Warme, J.E., and Davis, T.L., 1985. The Piaui basin: rifting and wrenching in an Equatorial Atlantic transform basin. In Biddle, K.T., and Christie-Blick, N. (Eds.), Strike-slip Deformation, Basin Formation, and Sedimentation. Spec. Publ.-Soc. Econ. Paleontol. Mineral., 37:143-158.

Date of initial receipt: 16 September 1996

Date of acceptance: 12 March 1997

Ms 159SR-003 

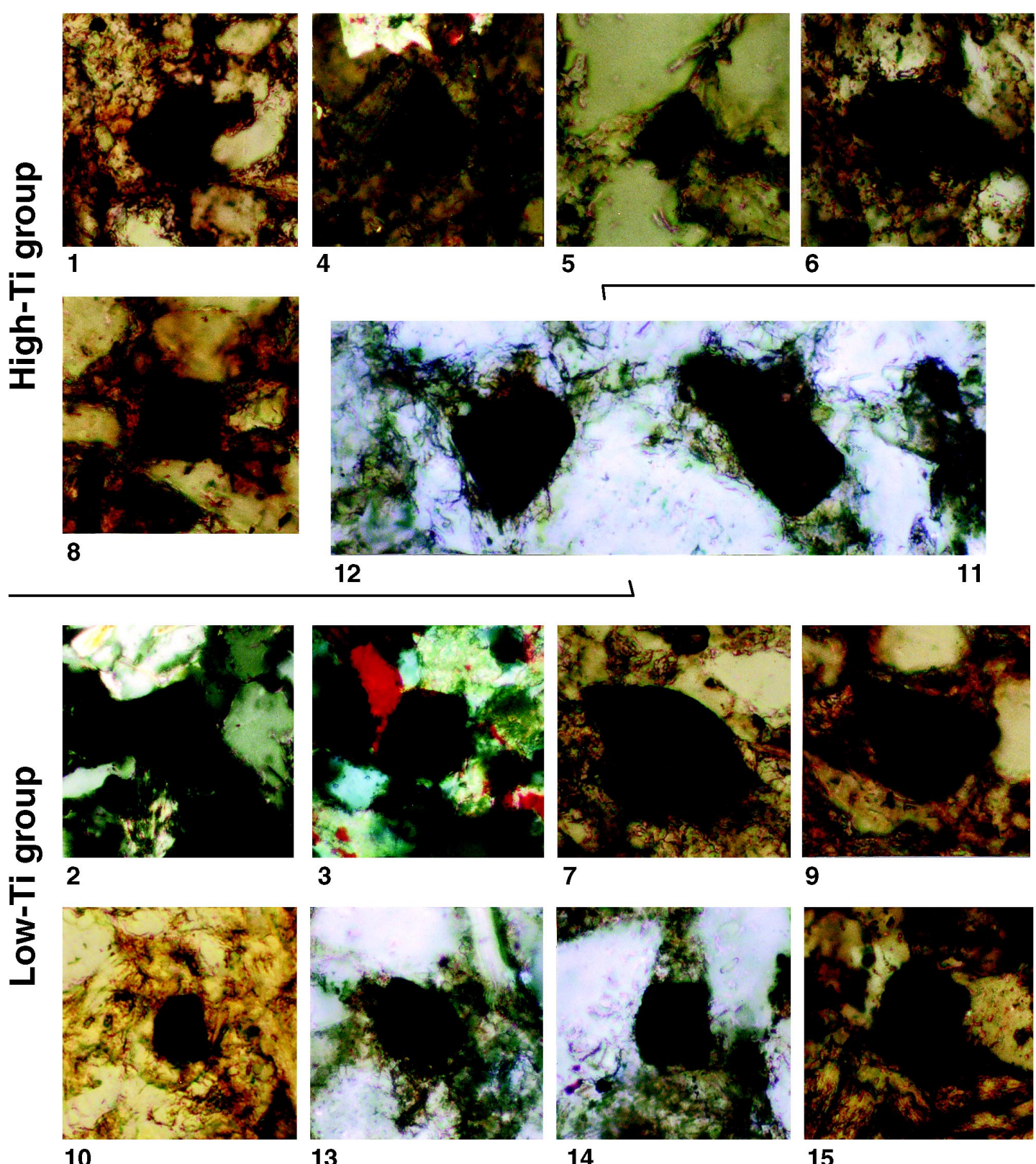

3
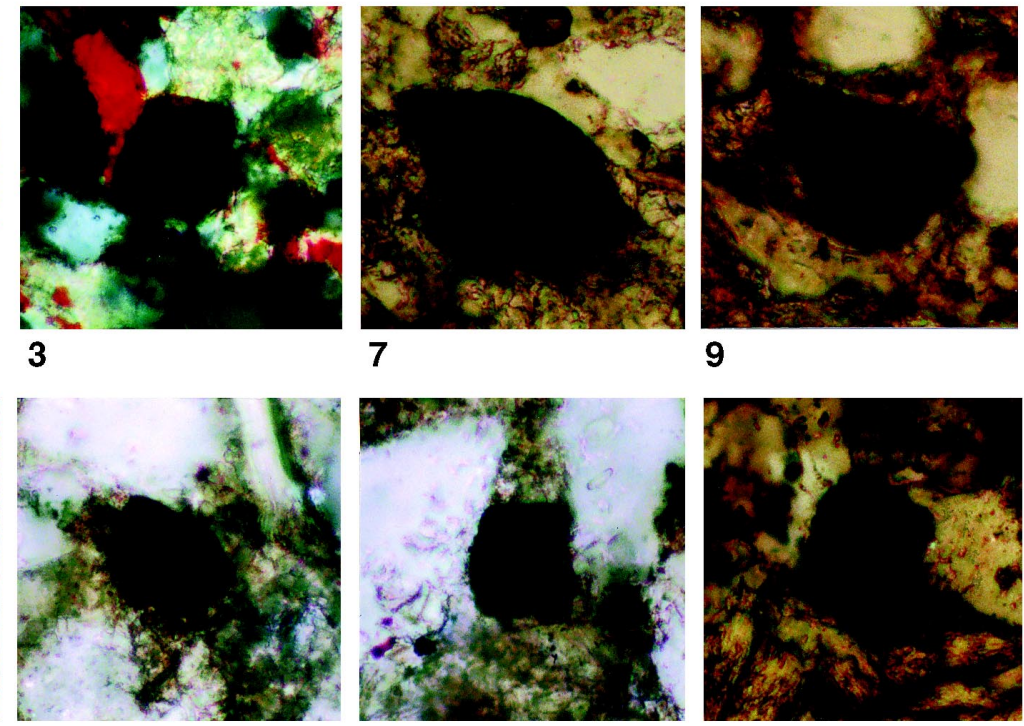

13

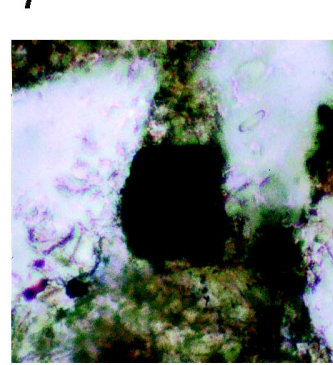

14

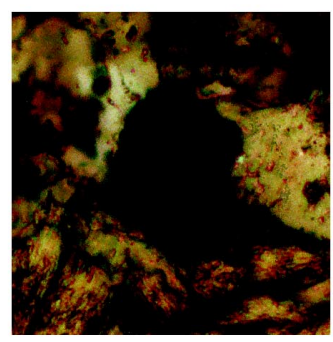

15

$100 \mu \mathrm{m}$

Plate 1. Photomicrographs of detrital chromian spinels. Figure numbers correspond to grain numbers in Tables 1 and 2. 